\title{
ヨウ化錫系に期待される第二臨界現象
}

\author{
愛媛大学大学院理工学研究科 㴊崎員弘
}

\section{Kazuhiro FUCHIZAKI: Second Critical Phenomena Expected in Tin Tetraiodide}

Thermodynamic anomaly of water is expected to be ascribable to the critical phenomena associated with the second (liquid-liquid) critical point, whose existence is, however, hardly proven directly. This is because the (hypothesized) point is thought to exist below the crystal homogeneous temperature, where no liquid bulk water can be probed. We have revealed that tin tetraiodide has quite a similar polyamorphic nature, but its second critical point is highly considered to lie in an accessible region.

\section{1. はじめに}

同じ重さの水なら, 凍った場合, その体積が増えると いうことは日常の経験から馴染みの深い現象かもしれな い.しかし, これは通常の物質では見られない, 熱力学 的にはきわめて異常な現象なのである。あるいは, その 特異性のゆえ, 水は生命や環境上の基本物質となり得た のかもしれない.

実は 21 世紀の現在に至っても水の熱力学異常性に対 する明確な物理的説明が与えられているとは言えない. ところが, この十年間において, この異常性についての 理解が急速に進展し, 全貌が明らかになりつつある。そ のヒントは定温圧縮率, 定圧熱容量, および定圧熱膨張 率のすべてが, あたかもマイナス $45^{\circ} \mathrm{C} に$ 向かって「発散」 しているように見える振る舞いにあった。すなわち, こ の温度にあたかも「臨界点」(図1中のC’点) があるよう に振る舞うのである。この臨界点は, 液相と気相の区別 ができなくなる気－液相境界の端に位置する臨界点 Cで はなく，下で述べる密度を異にする二液相境界の端点の ことであり, 前者と区別するために第二臨界点と呼ばれ る。したがって，第二臨界点について語る場合，同一成 分から成る, 密度の異なる二液相の存在が前提としてい る。しかし, この第二臨界点仮説の下では水の熱力学異 常を簡潔に説明できるだけでなく, 輸送係数異常も臨界 摇らぎに帰着させることができる. また, 前世期に見出 された非晶質氷の多形, ${ }^{1}$ 低密度非晶質水 (LDA) と高密 度非晶質水（HDA），が第二臨界点から延びる（準安定） 相境界 $(F)$ で隔てられているということが極めて自然 に説明できる.2)

しかしながら, このシナリオの最大の弱点は, 水の臨 界点が水点 $\left(T_{\mathrm{H}}\right)$ 以下にあるため, 仮説の根底にある臨 界点の存在自体を顕に示すことができない点である。し

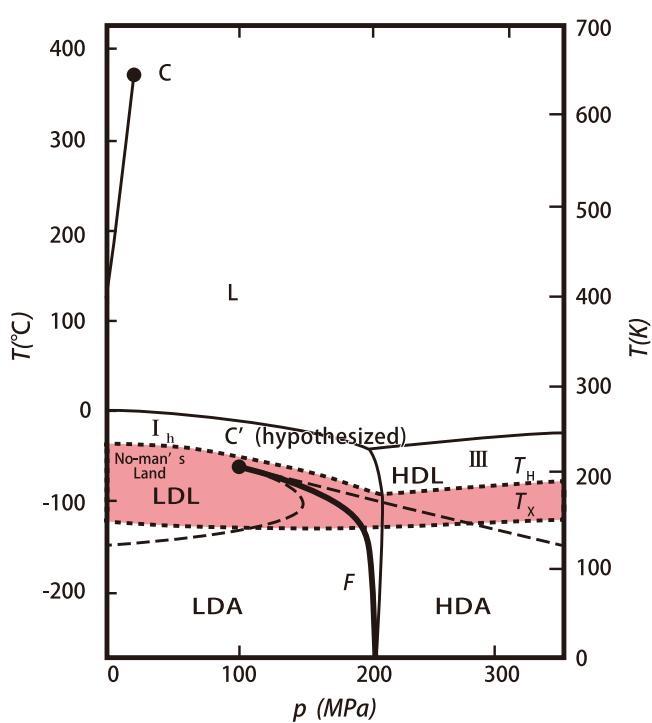

図1水の準安定非晶質多形を含んだ状態図。

(Polyamorphic phase diagram of water.) L : 液相, LDL: 低密度水, HDL：高密度水, LDA：低密度非晶質 水, $\mathrm{HDA}$ ：高密度非晶質水, $T_{\mathrm{H}}$ : 均一核生成温 度, $T_{\mathrm{X}}$ ：自発結晶化温度, $C^{\prime}$ : (仮想) 第二臨界点, $\mathrm{F}$ ：(準安定) 相境界, C’から延びる破線：スピノー ダル線. $T_{\mathrm{H}}$ と $T_{\mathrm{X}}$ の間の領域ではバルクの水を観察 することができず,「人類未踏の地」と呼ばれる。 水 $\mathrm{I}_{\mathrm{h}}$ と水 III の融解曲線と, それらの相境界線も参 考のため描いている ( $\mathrm{Y}$ 型の実線). 水 $\mathrm{I}_{\mathrm{h}}$ の融解曲 線が負勾配をもつことに注意されたい. 図左上の Cは気一液臨界点である。

たがって, LDAとHDAがそれぞれ融解したと考えられ る低密度水 (LDL) と高密度水 (HDL) を直接観察するこ とはできない.このため水をナノ領域に閉じ込めるなど して, その臨界点を水の安定領域に引き上げたり, 安定 領域にある水の輸送係数異常から逆に臨界点の「尻尾」 を引き出すことも試みられている.3)一方, 筆者らはヨウ 
化錫系が水同様の不定形多形状態図を有することを明 らかにしてきた。この結果, ヨウ化錫においては第二臨 界領域に立ち入れる可能性がきわめて高い. 本稿では, こうした経緯について述べてみたい。

\section{2. 圧力誘起非晶質化現象}

結晶に圧力を印加すると一般的には高対称の構造に 転移し得る。ところが, 正四面体対称性 $\left(\mathrm{T}_{\mathrm{d}}\right)$ をもつヨ ウ化錫分子からなるヨウ化錫結晶 (空間群 $\mathrm{Pa} 3$, 図2) は 十数 $\mathrm{GPa}$ の圧力印加で非晶質化を起こすことが見出され

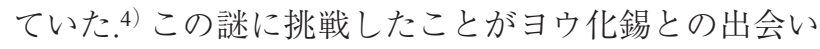
となった. 当初, この問題は正四面体が三次元空間を充 填できない点に帰着できると考えていた(乱れた四面体 分子配置は後に見出される低密度非晶質状態に相当す る). 四面体分子は電気的に中性であるから四面体頂点 位置にあるヨウ素間にvan der Waals相互作用をもつ作用 点模型を考元, 分子動力学法による加圧「実験」を行っ てみたところ, 常温での圧縮特性をよく再現するもの の, 加圧とともに分子間距離を縮めつつ, <111>周りに 分子対は回転し, 充填率を高めるだけで, 結晶状態は数 十 GPaまできわめて安定であった.5) ところで, 圧力非晶 質化現象を起こす物質の共通する性質として, この負勾 配の融解曲線が指摘されていた ${ }^{6}$ 非晶質化を固体状態 での融解と見なすと結晶融解に際して何らかの異常が現 れることを期待した. 同模型の圧力下で加熱シミュレー ションを行ってみたところ, 予想に反して, 加熱に対し ても結晶相 (CP-I) は安定で, その融点は圧力とともに
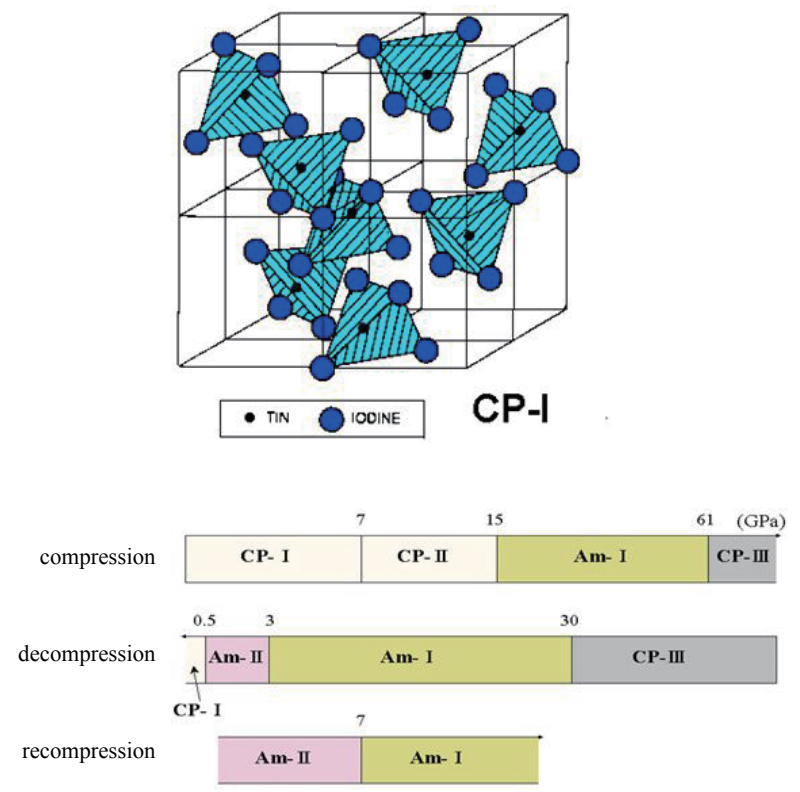

図2（上）ヨウ化錫結晶相 (CP-I) の単位胞. (The unit cell of CP-I at ambient conditions.) 常温・常圧での 格子定数は $12.273 \AA$. (下) 常温での CP-Iの圧力 誘起構造変化. (The sequence of pressure-induced structural transitions observed at room temperature.)
単調に上昇した、7)この実験での検証が、ヨウ化錫が水型 多形状態を有するという議論につながることになる.

本論に入る前に, 浜谷らによってダイヤモンドアンビ ルセルを用いて同時期に見出された重要な知見につい て述べておきたい，それは常温でのヨウ化錫の構造相転 移シーケンス（図2）を明らかにしたことである.CP-I は7 GPaで別の結晶相 (CP-II) に一次転移し, その後に $15 \mathrm{GPa}$ 付近で非晶質状態 (Am-I) を経由し, 最終的に分 子解離により $61 \mathrm{GPa}$ でヨウ素の fcc 相 (CP-III) に転移す る. ${ }^{8)}$ さらに重要なことはCP-IIIからの減圧過程でAm-I が3 GPaで別の新たな非晶質状態 (Am-II) に遷移するを 見出したことである ${ }^{8}{ }^{8} \mathrm{Am}-\mathrm{II}$ の再加圧により，その安定 限界が7 GPaであることも見出した. $\left.{ }^{8}\right)$ 最初に見出されて いたAm-IはHDAであり，後で見出されたAm-IIがLDA である. 水と同様, 異なる密度の非晶質多形が見出され たわけである。

\section{3. ヨウ化錫系のポリアモルフィズム}

\section{1 融解異常}

マルチアンビル型プレス装置を用いた高圧下での放射 光X線その場観察実験によりヨウ化錫の融解を直接観 測し, 融解曲線を決定したところ, やはり, 温度一圧力 相図で正勾配となる曲線となった(図3)。しかるに, シ ミュレーション結果とは異なり, 約 $1.5 \mathrm{GPa}$ で屈曲する ことがわかった.9 それれりり高圧側では融解曲線はほぼ

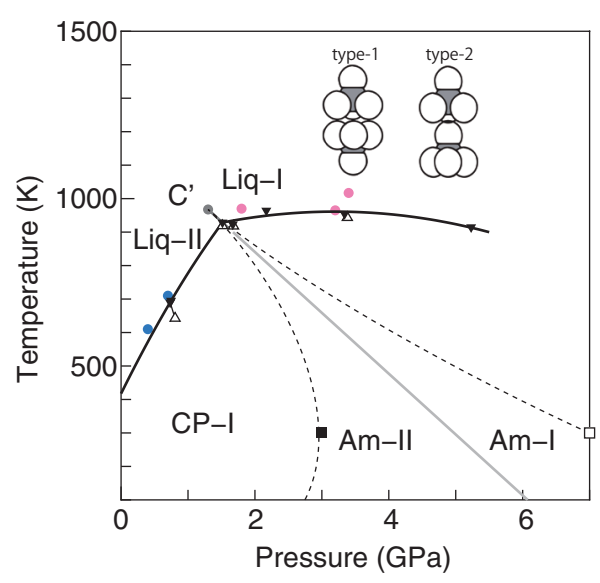

図3 ヨウ化錫の状態図. (Polyamorphic phase diagram of tin tetraiodide.) 結晶相 CP-I の融解曲線 (太実線, $\triangle$ : 昇温過程で回折線を確認できた最高温度, $\boldsymbol{\nabla}$ : 融点) と二液相 (○：低圧液相Liq-II の観測 点, : 高圧液相 Liq-I の観測点). 擬二正則溶体 模型から得られる第二臨界点 C' から延びる相境界 (淡直線) とスピノーダル線 (破線)。後者は低密度 非晶質状態 Am-II と高密度非晶質状態 Am-I の存 在限界（それぞれ，ロと吕)を通る。(挿入図) 面対 面の最近接分子間配向 (type-1) と頂点対面の分 子間配向 (type-2). 編集部注 : カラーの図はオン ライン版を参照下さい. 
フラットになる。これはすなわち, 約 $1.5 \mathrm{GPa}$ 以上では 融解前後で密度変化が小さく, 屈曲点圧力より低圧側 の液体とは異なる密度を有する液体の存在を示唆する。 $1.5 \mathrm{GPa}$ より低圧側の液体を徐冷した場合, CP-Iの有す るPa3 刘称性をほぼ回復するのに対し, 高圧側液体を徐 冷した場合, 同対称性では説明できない回折線が多く現 れること ${ }^{9)}$ からも高圧液体の存在可能性が期待された.

\section{2 低圧液体と高圧液体}

そこで, 屈曲点圧力より低圧側と高圧側の液体構造の 直接観察に挑んだ.この成功には克服しなければならな い問題があった，前節で述べた融解実験では融解後の液 体試料を保持する必要がなかったが, 構造観察には液体 を長時間安定に保持できる容器が必要となる。 ヨウ化物 はきわめて化学反応性に富む物質である。高温下でこ の傾向は助長される.ヨウ化錫と化学反応を起こさず, X線に対して透明で, かつ, 高圧実験に耐えられる試料 容器として, 試行錯誤の結果, ダイヤモンドにたどり着 いた．まず常圧でのヨウ化錫液体の構造 ${ }^{10)}$ を明確にした 上でダイヤモンド容器を用いた高圧下での放射光 $X$ 線そ の場観察から液体の局所構造変化の有無を探った，そ の際, 試料圧力を正確に見積もるために, 試料容器内を ダイヤモンドディスクの可動ピストンで仕切り，その 両側に試料と圧力マーカーである $\mathrm{NaCl}$ を配置する方法 を確立した. ${ }^{11}$

低圧液相（Liq-II）と高圧液相（Liq-I）の代表的構造因 子 $S(k)$ と還元動径分布関数 $\left.G(r){ }^{12}\right)$ を図4に示した. 1 気圧下では 2 節で述べた模型を融解させて得られる液体 が実験で見出された構造因子10）をよく再現する。この模
型液体の最近接分子間配向の様子を調べたところ, 充填 度を上げる配向として知られている type-1 と type-2 の配 向 (図3挿入図) がほほ同じ割合で見出された. ${ }^{13)}$ type-1 配向は結晶状態での最近接分子間配向であるが, type-2 配向は融解によって初めて現れるものであることに注意 されたい. 構造因子の約 $2.7 \AA^{-1}$ 以上の成分は分子内相関 を表す，実際，正四面体対称性を考慮した分子形状因子

$$
S_{\text {intra }}(k)=1+\frac{8}{3} j_{0}\left(k r_{\mathrm{Sn}-\mathrm{I}}\right)+\frac{12}{5} j_{0}\left(\sqrt{\frac{8}{3}} k r_{\mathrm{Sn-I}}\right)
$$

でよく記述できる.ここでj 0 は零次の球Bessel 関数であ る. $k \geq 2.7 \AA^{-1}$ 成分の式 (1)へフィット (点線) から分子 内の $\mathrm{Sn}-\mathrm{I}$ 距離 $r_{\mathrm{Sn}-\mathrm{I}}=2.65 \AA$ が得られる. $S(k)$ の Fourier (逆) 変換が $G(r)$ となる. 常圧の $G(r)$ は鋭い二本のピー クで特徵付けられる。これらは分子内の Sn-I と I-I相関 を表し, 前者のピーク位置は上で得られた $2.65 \AA$, 後者 の位置は $4.33 \AA$ となり (図 $4 \mathrm{~b}$ 縦破線), それらの比は $\sqrt{\frac{8}{3}}$ に等しい。 これは, 分子の正四面体対称性を保証する。

$0.4 \mathrm{GPa}$ 下でも $S(k) の k \geq 2.7 \AA^{-1}$ 成分は依然として 式(1) を満たしている (図4a中段). 対応する $G(r)$ はその 位置が縦破線に一致する2本のピークをもつ.すなわち, この圧力下でも分子は健在で対称性 $\mathrm{T}_{\mathrm{d}}$ を有したままで あることがわかる，ところが $G(r)$ の第二ピーク幅が有意 に広くなっていることが見てとれる。この理由は分子動 力学法シミュレーションを援用して理解できる. シミュ レーションから得られる $G(r)$ を重悋て描いた（図4b 中段)。これは部分還元動径分布を重ね合せたものであ る. Sn-Sn間の部分動径分布の第一ピーク位置から最近
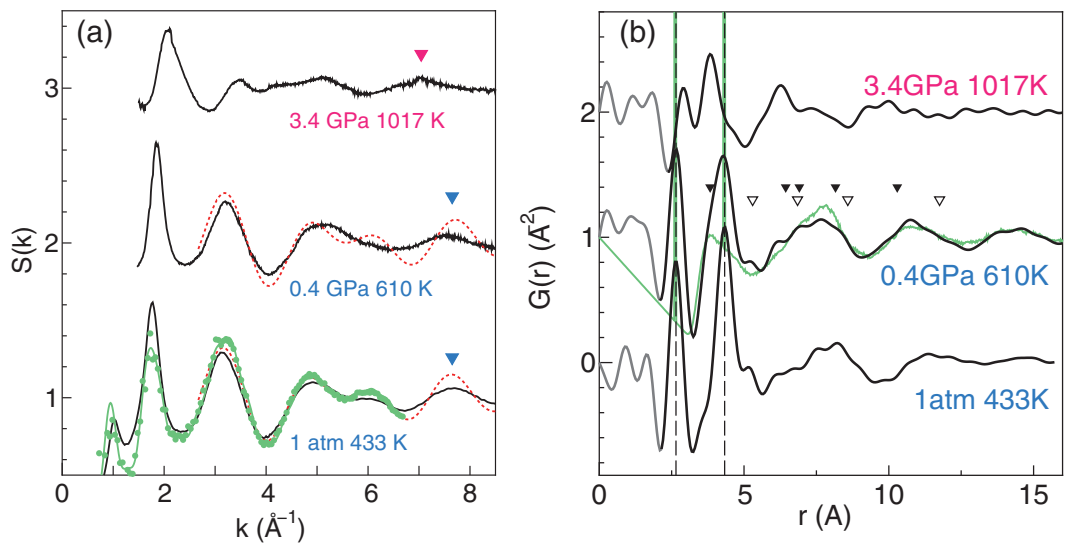

図4（a）各表示状態での構造因子 (実線, 縦方向に1ずつずらして表示). (Normalized structure factor $S$ plotted against wavenumber $k$ at the condition indicated.) 常圧の構造因子は分子動力学シミュレーションから求めたもの（の付細 線）と比較している。低圧液体構造は約 $2.7 \AA^{-1}$ 以上の成分を分子形状因子にフィット可能である (点線). $8 \AA^{-1}$ 付近のピーク $(\boldsymbol{\nabla})$ が高圧液体では低波数側にシフトする。（b) 各表示状態での還元動径分布関数 (RRDF, 縦

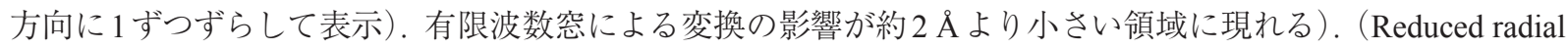
distribution function (RRDF) $G$, inverted from $S$, plotted against radial distance $r$.) 常圧での四面体分子内の $\mathrm{Sn}-\mathrm{I}$ 間 距離 $(2.65 \AA)$ と I-I 間距離 $(4.33 \AA)$ の位置を 2 本の縦破線で示す. 分子動力学シミュレーションから得られる RRDF $(0.4 \mathrm{GPa}, 610 \mathrm{~K})$ をもとに推測した最近接分子間のI-I間隔を $\nabla$ (type-1 配向の場合) と 場合) で示す. 
接分子間距離が推定できる. 実験で得られる $G(r)$ との 一致の良さから, この距離は実際の最近接分子間距離に 近いはずである，そこで，最近接分子間がtype-1 および type-2配向をとった場合の最近接分子間の I-I 距離を,

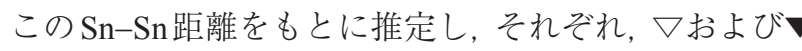
で示した，注目すべきはtype-2配向をとった場合，分子 内 I-I距離以内に別の分子のIが近づける点である。す なわち, 最も短距離の分子間 I-I 長 $3.83 \AA$ が分子内 I-I 長 より短くなる. $G(r)$ の第二ピークの低 $r$ 側の非対称な広 がりは,この分子間 I-I相関からの寄与であると結論し てよいであろう.

さて, $3.4 \mathrm{GPa}$ 下では事態は一変する. $S(k)$ の高波数 成分の形状は低圧側のそれとは定性的に異なり（図4a 上段），もはや式(1)で表せない．対応する $G(r)$ (図4b 上段）も低圧側での様相とは一変する。低 $r$ 側で 2 本の ピークはもつものの, その位置はもはや縦破線上にはな い. 分子内 I-I間距離は $4.33 \AA$ よりは確実に縮み, 加圧 したにもかかわらず, 分子内 Sn-I間距離は常圧の長さ より伸びている! この驚くべき事実は分子がもはや 正四面体形状を有していないことを示している，さらに 驚くべきことに, 分子内I-I間に相当する長さ $3.82 \AA$ は $0.4 \mathrm{GPa}$ 下で type-2 配向した最近接分子の I-I 間距離にき わめて近い.

ところで, $\mathrm{I}_{2}$ が金属化する際の最近接 I-I 間距離は $3.10 \AA$ である ${ }^{14)}$ が, 最初に伝導をもつのは前者に直交す るI-I間で，その距離は $3.6 \AA$ である. ${ }^{14)}$ 高圧結晶相 CP-II (図2)の構造は解かれていないが, それに至る直前で最 近接分子間I-I距離が $3.6 \AA$ になっていることから, CP-II は金属相であると予想されている. ${ }^{8)} 3.4 \mathrm{GPa}$ 下での最近接 I-I間長は, この長さ $3.6 \AA$ に近い. $G(r)$ の第二ピーク幅 は $0.4 \mathrm{GPa}$ 下でのそれよりは狭く, このことから $3.4 \mathrm{GPa}$ 下ではすでに分子内, 分子間の区別がなく, 単に I-I間距 離の分布を表していると考えられる。つまり, $3.4 \mathrm{GPa}$ では高分子化が起こっており，I-I間は金属結合に近い， 単一の長さで特徽づけられると結論できそうである。こ う考えると, 固体内での type-1 配向が融解により容易に 分子反転できて type-2配向になれる意義は大きい. 反転 が許されない固体では金属結合距離内にI同士を近づけ るために $7 \mathrm{GPa}$ 必要であるが, type-2であれば2 GPa未満 でその距離内に近づけられるということである.

こうした一連の結果が得られた後, 驚嘆すべきことが わかった，図4bで示した低圧・高圧液体の $G(r)$ は，ほ ぼ定量的にAm-II と Am-Iの $G(r){ }^{15)}$ に一致するのであ る!この事実から, それぞれの液相を低圧液相Liq-II と高圧液相 Liq-I と名付けた. Liq-II と Liq-Iは，それぞれ $\mathrm{Am}-\mathrm{II}$ と Am-Iが融解したものにほかならない.これらの 液体構造の差は, その局所構造の相違となって現れる. 図4aに示した $S(k)$ からわかると㧍り，Liq-IIの $S(k)$ で
$8 \AA^{-1}$ 付近に現れるピークが Liq-Iでは低波数側にシフト したように見える. 加圧に反して「伸びる」ような局所 変化は単純には説明できない. 実空間での変化を明確に することは今後の研究課題の 1 つである. これらの局所 構造の特徵を基に融点直上の液体構造を調べたところ, 融解曲線の屈曲点より低圧側で Liq-II が, 高圧側で Liq-I が観測された（図3)。本節で述べたことは局所構造を異 にする液体が存在するということである，にもかかわら ず, すでに液「相」と呼んでいる。この理由は 3.4 節で明 らかになる。

\section{3 ヨウ化錫系のポリアモルフィズム}

以上述べたことですでに「役者」は揃った．本節では， これらの相 (状態)の熱力学関係について述べる.

これらの状態間の関係を最も自然に説明できるのは, やはり，第二臨界点シナリオではないかと考元, 擬正則 二溶体模型 ${ }^{16)}$ の構築を試みた. ${ }^{12)} こ の$ 模型において重要 なパラメー夕は二溶体の混合エネルギーとエントロピー の比である.ヨウ化錫に関しては熱力学的特性に関す る情報がきわめてそしい，逆に言えば，現段階ではわれ われが見出した各状態の存在領域に矛盾しない範囲で 熱力学特性を自由に選択可能である。 そこで, まずは温 度 - 圧力相図内でLiq-II (Am-II)/Liq-I (Am-I) 間境界線 の傾きが負になるような比の值の範囲内で模型のパラ メー夕值の探索を始めた. 模型に含まれるすべてのパラ メー夕值を決めるためにはさらに具体的な仮定が必要 となる，そこで, 融解曲線の屈曲点 $(930 \mathrm{~K}, 1.52 \mathrm{GPa})$ が CP-I/Liq-II/Liq-I相の三重点であると仮定した．この仮定 の妥当性に関しては後に述べる。 また, 第二臨界点が正 圧側に存在すると仮定し, その臨界圧力を $0.5 \mathrm{GPa}$ であ ると置いてみた。これらの仮定と2節で紹介したAm-II と Am-Iの安定限界が，それぞれ， $7 \mathrm{GPa}$ と $3 \mathrm{GPa}$ である という事実から模型に含まれるすべてのパラメー夕值を 決めることが可能となる. 詳しくは文献12）を参照され たい. $1120 \mathrm{~K}$ が臨界点温度として得られた。このときの 状態図が同文献内の図1である.

ところが, 後の実験で上記仮定とは矛盾する重要な発 見があった. Liq-II相内で昇温しながら構造を観察した ところ, $1.0 \mathrm{GPa}, 950 \mathrm{~K}$ と $1.26 \mathrm{GPa}, 1050 \mathrm{~K}$ の点を結んだ 経路上でLiq-Iを見出せなかった. ${ }^{17)}$ 先のパラメータ值を 基にした状態図では, この経路は Liq-II/Liq-I境界を横切 ることになってしまう.すなわち, 第二臨界点が存在す るとしたら，それはこの経路より高圧側にないといけな い. そこで, 臨界点圧力を $1.3 \mathrm{GPa}$ に再設定し, 再計算し

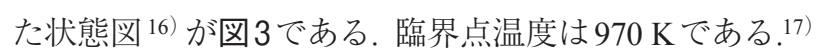
擬正則二溶体模型はLiq-II と Liq-Iを，それぞれAm-II とAm-Iの安定液相であると関係づける。そそれでは両非晶 質状態の安定固相があるのであろうか？ 例えば, Am-II と Am-Iに対する安定固相が，それぞれ，CP-I とCP-IIで 
あると考えることもできるであろう。CP-IIの構造が未 決定であることを良いことに, この線に沿って夢を膨ら ませることが可能である，固体が融解した場合, 特に高 密度下では, 融解後も固体構造の特徵が局所的に残存 すると考えるのは自然であろう，例えば, CP-I中の最近 接分子対はLiq-IIの type-1 配向として残存する。こうし た局所的分子配向状態に擬スピンをアサインすると配向 秩序をPotts 模型で記述できる，そうすると Liq-Iの安定 固相では異なるタイプの擬スピンの秩序状態だと考える ことができる。これら擬Potts スピンの混晶系の（配向秩 序の）融解は Patashinski-Son模型 18),19）を基に議論でき る. Liq-II と Liq-Iに対する安定結晶の配向状態数はまっ たく任意に，それぞれ，4 (低対称) と48 (高対称) にと り, 擬正則溶体模型で仮定した三重点と臨界圧力を用

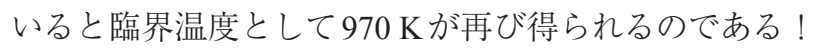
でき上がる状態図は図3に示した擬正則二溶体模型の結 果とほとんど変わらない. 計算の詳細を含め, 文献17） を参照されたい．

まとめると, 第二臨界点の存在を仮定すればヨウ化 錫系の構造変化に関する知見は矛盾なく簡潔に理解で き, 擬正則二溶体模型, Patashinski-Son模型，ともにほ ぼ同等な状態図を与えることができる, 得られた状態図 （図3）が水のそれ（図1）に酷似していることに注意さ れたい.ヨウ化錫系では第二臨界圧力值を仮定したが, この仮定が各状態の存在域を説明するために必須であっ たことを考慮すると，その位置推測は妥当である，その 臨界域に現実的に足を踏み入れることが可能である点が 水系との決定的な差である!

\section{4 密度測定}

前節では両液体の局所構造の変化に言及した. 各液 体を相と呼ぶには秩序変数である密度が異なる值で特 徵づけられる必要がある。不定形である液体の密度測 定は, とりわけ極限条件下に扔いて, 決してトリヴィア ルな問題ではない，われわれは単色放射光X線吸収測定
から両液体の密度を推定した。高圧下での放射光X線 その場吸収測定からの密度推定は完全に確立した方法 ではなかったので, $0.42 \mathrm{GPa}$ 下でCP-Iが融解する際の

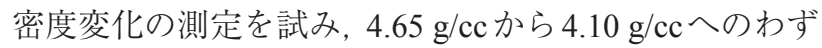
か $0.55 \mathrm{~g} / \mathrm{cc}$ の変化が有意に検出できることを明らかに した ${ }^{20)} \mathrm{CP}-\mathrm{I}$ 内では同時に回折実験を行い, 格子定数か ら求まる密度值と誤差範囲内で一致することを確認で きた。

この技術を使って融解曲線屈曲点付近で屈曲点より 低圧側と高圧側の液体密度測定を行った，本質的に重 要な結果を抽出して図5にまとめた. 圧力值と温度值に は試料内の圧力勾配と温度勾配の誤差があり, 本実験 の場合，それぞれ， $0.05 \mathrm{GPa}$ と〜30 K と見積もってい る. 図 $5 a$ とbの状況は融解曲線屈曲点のすぐ低圧側と 高圧側を示していると考えていただきたい. 屈曲点のす ぐ低圧側では融解に際して〜 $5.0 \mathrm{~g} / \mathrm{cc}$ から〜 $4.6 \mathrm{~g} / \mathrm{cc} の$ 約 $0.4 \mathrm{~g} / \mathrm{cc}$ のドロップが認められるのに対し，すぐ高圧 側では融解しても〜 $4.9 \mathrm{~g} / \mathrm{cc}$ の密度值に変化が見られな い(図 (a)，（b）に扔いて固相内での密度が若干不一致 である理由については検討中である)。これらの密度変 化は屈曲点の両側での融解曲線の傾きの変化とまった く矛盾しない.このことから Liq-II は Liq-I は転移点付近 で $0.4 \mathrm{~g} / \mathrm{cc} く ら い$ 異なる相であると結論できる. Liq-IIが LDL， Liq-IがHDLである.

さて, Liq-II と Liq-Iが不連続転移境界で隔たれている ことを示す必要がある。すなおち, この境界をLiq-II側 からまたいだ時, 〜 $0.4 \mathrm{~g} / \mathrm{cc}$ の密度の跳びを観測しなけ ればならない。これに関しては近々朗報を伝えられると 考えている.

\section{5 水型ポリアモルフィズム}

前2節で述べたことからポリアモルフィズムに関して ヨウ化錫が水と類似した特徵を備えていることを理解し ていただけたはずである，それでは，冒頭に述べた水の ポリアモルフィズムを説明する第二臨界点シナリオ2）を
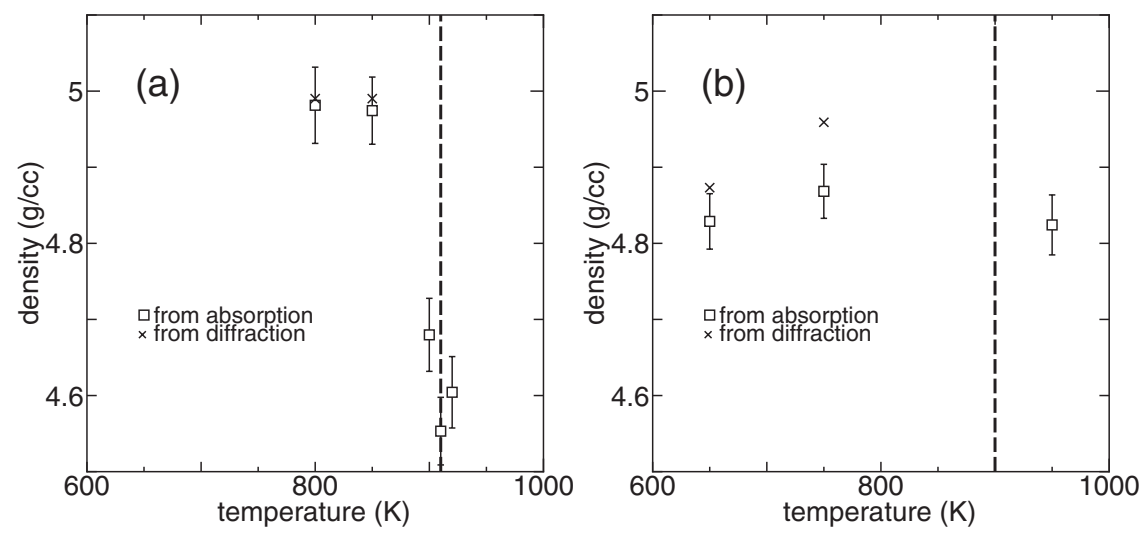

図5 融解時の密度の変化. (The variations in densities upon melting.) (a) 1.6 GPaで融解した場合. (b) $1.7 \mathrm{GPa} て ゙$ 融解 した場合. $\square$ : X線吸収実験からの推定，×：X線回折実験からの推定，破線：融点. 
ヨウ化錫に対しても適用できるはずである.文献2）で 用いられている模型のプロトタイプ模型を含まれるパラ メータの值を変えて適用してみたところ, 擬正則二溶体 模型やPatashinski-Son模型の第二臨界点とほほ同じ位 置に第二臨界点が現れる，興味深いのは，さらに密度極 大が臨界点より高温側に現れる点である. ${ }^{21)}$ 現在, 実験 にて検証を行っている。この存在が示されれば水との類 似性がますます顕著になる。

\section{6 液相間転移}

液相間転移が起こるための条件として，しばしば融解 曲線に極大が現れること 22) が取り沙汰される。偏晶型 状態図に現れる液相線からのアナロジーによるものかも しれない. 融解曲線が極大をもつことより, その傾きが 不連続に変化する点を有することが本質的ではないかと 筆者は考えている. そういう特異点の有無は, 三重点を 境界とする微分方程式の解として融解曲線が得られるか 否かで判定できそうである.23),24)

\section{4. おわりに}

ポリアモルフィズム研究に関してヨウ化錫が水の代 替物質となり得ることを説いてきた。図 1 と図3を比べ れば筆者の意困は一目瞭然であろう。これらの状態図構 成に至った背景にある, 第二臨界点仮説が複雑な状態 間の関係を簡潔に整理してくれる。ヨウ化錫に見出され た圧力誘起非晶質化現象は正に氷山の一角でしかなく, かくもリッチな物理が水面下に潜んでいたわけである.

\section{謝 辞}

ヨウ化錫に関する一連の高圧実験による研究はお茶 の水女子大学の浜谷先生と行ってきたものである. 理論 屋の筆者が放射光を利用した高圧実験を行えたのは原 子力機構の片山氏の手ほどきを受けたからである.

\section{文 献}

1) O. Mishima, L. D. Calvert and E. Whalley: Nature 314, 76 (1985).

2) K. Stokely, M. G. Mazza, H. E. Stanley and G. Franzese: Proc. Natl. Acad. Sci. U.S.A. 107, 1301 (2010).

3) V. Holten, C. E. Bertrand, M. A. Anisimov and J. V. Sengers: $J$.
Chem. Phys. 136, 094507 (2012).

4) Y. Fujii, M. Kowaka and A. Onodera: J. Phys. C 18, 789 (1985).

5) K. Fuchizaki, M. Isobe, Y. Fujii, K. Sato and N. Hamaya: J. Phys. Soc. Jpn. 66, 1575 (1997).

6) E. G. Ponyatovsky and O. I. Barkalov: Mater. Sci. Rep. 8, 147 (1992).

7) K. Fuchizaki, S. Sugiyama and Y. Fujii: J. Chem. Phys. 112, 10379 (2000).

8) N. Hamaya, K. Sato, K. Usui-Watanabe, K. Fuchizaki, Y. Fujii and Y. Ohishi: Phys. Rev. Lett. 79, 4597 (1997).

9) K. Fuchizaki, Y. Fujii, Y. Ohishi, A. Ohmura, N. Hamaya, Y. Katayama and T. Okada: J Chem. Phys. 120, 11192 (2004).

10) K. Fuchizaki, S. Kohara, Y. Ohishi and N. Hamaya: J. Chem. Phys. 127, 064503 (2007).

11) K. Fuchizaki and N. Hamaya: Phys. Rev. B 84, 144105 (2011).

12) K. Fuchizaki, T. Hase, A. Yamada, N. Hamaya, Y. Katayama and K. Funakoshi: J. Chem. Phys. 130, 121101 (2009).

13) K. Fuchizaki, I. Nezbeda and Y. V. Kalyuzhnyi: unpublished work.

14) K. Takemura, K. Sato, H. Fujihisa and M. Onodera: Z. Kristallog. 219, 749 (2004).

15）浜谷 望：高圧力の科学と技術 $\mathbf{1 5}, 120$ (2005).

16) E. G. Ponyatovsky: J. Phys.: Condens. Matter 15, 6123 (2003).

17) K. Fuchizaki, N. hamaya, T. Hase and Y. Katayama: J. Chem. Phys. 135, 091101 (2011).

18) A. C. Mitus and A. Z. Patashinski: Phys. Lett. A 87, 79 (1982).

19) L. D. Son, G. M. Rusakov and N. N. Katkov: Physica A 324, 634 (2003).

20) K. Fuchizaki, N. hamaya and Y. Katayama: J. Phys. Soc. Jpn. 82, 033003 (2013)

21）K. Fuchizaki: 出版予定.

22) E. Rapoport: J. Chem. Phys. 46, 2891 (1967).

23) K. Fuchizaki: J. Chem. Phys. 139, 244503 (2013).

24) K. Fuchizaki and K. Okamoto: Phys. Lett. A, in press.

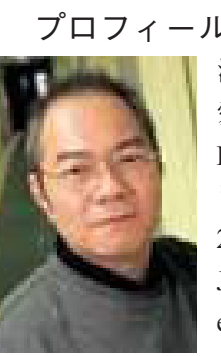

㴊崎員弘 Kazuhiro FUCHIZAKI 愛媛大学大学院理工学研究科

Department of Physics, Ehime University 于 790-8577 愛媛県松山市文京町 2-5

2-5 Bunkyo-cho, Matsuyama, Ehime 790-8577, Japan

e-mail: fuchizak@phys.sci.ehime-u.ac.jp 最終学歴：大阪大学大学院基礎工学研究科 専門分野: 非平衡統計力学 現在の研究テーマ：ポリアモルフィズム 趣味：誤解を恐れずにいえば, 高圧実験 